\title{
Jy moet jou naaste asook jou vyand liefhê: Liefde in Lukas 6:27-38 en 10:25-37
}

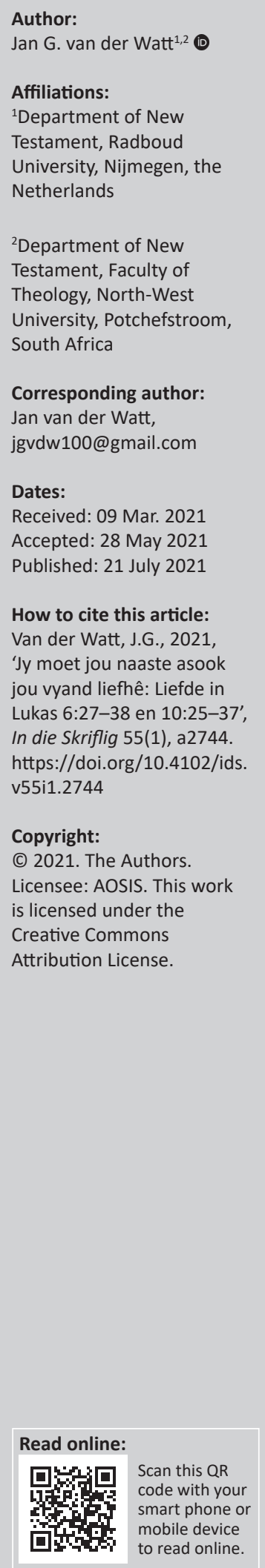

You must love your neighbour as well as your enemy: Love in Luke 6:27-38 and 10:25-37. The background of this study is found in the common perception that love as concept is linked to Jesus as basic ethical commandment and identity marker of Christians. This view has been challenged lately, and will be reconsidered in light of Luke. The question addressed as objective of this article is whether the Lukan Jesus may be called the 'Jesus of love', as Jesus refers only twice (Lk 6:27-38 and 10:25-37) to intense personal love ( $\dot{\alpha} \gamma \alpha \pi \alpha \dot{\alpha} \omega$ - akin to love typical of family or friends). Following established exegetical approaches, all the uses in Luke of the word groups

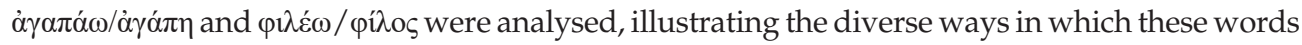
are used by Luke. The two contexts referring to intense love were analysed in more detail and it was shown that love functions as the overarching term for other terms referring to concepts such as mercy, compassion, good deeds, non-retaliation and other concepts linked to the underdogs, enemies, the poor, oppressed or women in Luke. The result of the investigation was that, although the Lukan Jesus does not use the term à $\gamma \alpha \pi \alpha \dot{\omega} \omega$ frequently, the idea of love as overarching term is indirectly attested through the use of these other terms describing compassion, respect, assistance, mercy, et cetera. In this sense, the Lukan Jesus is the 'Jesus of love'.

Contribution: The contribution to research lies in the detailed description of the semantics of love in Luke and showing that Jesus' ministry might, with good reason, be described as a ministry of love.

Keywords: love for enemies; love in Luke; neighbour in Luke; Luke 6:27-38; Luke 10:25-37.

\section{Inleiding}

'n Vraag is of Jesus in die Lukasevangelie as die verkondiger van liefde uitgebeeld word, veral in die lig daarvan dat die Lukaanse Jesus eintlik net in twee kontekste na die intens persoonlike liefde (wat met die meer intense familieliefde of vriendskapsliefde verbind kan word) verwys.

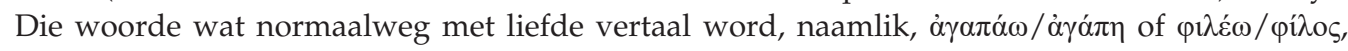
word wel meer kere deur Lukas gebruik, maar met variërende intensiteit en betekenis soos weldra aangetoon sal word.

Daar is al op verskillende wyses op bogenoemde probleem gereageer. Aan die een kant word die konsep liefde as essensiële deel van die Lukaanse Jesus se boodskap aanvaar. Popkes (2013:536), byvoorbeeld, het geen twyfel dat 'the canonical Gospels agree that the love commandment embodies the central motive of Jesus' ethics'. Dit word ook deur vele ander van Lukas aanvaar. ${ }^{1}$ Ander begrippe soos genade of meegevoel wat 'so central to Luke's thought' is (Scheffler 2006:82), ${ }^{2}$ word as uitdrukkings van liefde gesien, wat dan beteken dat liefde indirek en by wyse van hierdie ander begrippe deur die hele Evangelie voorkom.

Aan die ander kant, is die opinies meer afwysend van aard. Hays (1996:193-200), byvoorbeeld, verwerp die idee dat liefde 'n sentrale konsep in die etiek van die Nuwe Testament en spesifiek van Lukas is: vir 'a number of the major New Testament writers, love is not a central thematic emphasis' (p. 200). Hays (1996:200-201) gee wel toe dat Lukas nie teen die gebruik van liefde is nie. Wanneer hy (Hays 1996:112-137) wel die etiek van Lukas-Handelinge bespreek, verwys hy nie na die rol van liefde in die Evangelie nie. Hierdie afwysende opinie word ook deur verskeie ander gedeel. ${ }^{3}$

1.Tannehill (2014:533-541) gee'n gebalanseerde uiteensetting van die etiek van Lukas-Handelinge.

2.In sy 1997 kommentaar, meen Green (1997:270) dat liefde een van die onderskeidende kenmerke van die Lukaanse etiek is.

3.'n Paar voorbeelde behoort die punt genoegsaam te illustreer: Holladay (2005:176-185) bespreek 'aspects of Luke's theology' maar noem nie liefde nie, al verwys hy na gedeeltes waar die woord gebruik word. In sy oorsig fokus Bovon (2005:546-554) op die noofmomente van die etiek van Lukas-Handelinge, maar raak die tema van liefde eintlik nie aan nie. Wanneer Green (2013:546-549) Lukas se 'theological motifs' bespreek, verwys hy ook nie na liefde as tema nie. In sy 270 bladsye oor rykdom in Lukas staan Christopher Lukas se 'theological motifs' bespreek, verwys hy ook nie na liefde as tema nie. In sy 270 bladsye oor rykdom in Lukas staan Christopher
Hays (2010) alleen 20 bladsye aan die begrip liefde ( $\alpha$ yráa) af. Burridge (2007) staan basies twee bladsye aan die tema van liefde af wanneer hy die Lukaanse etiek bespreek (pp. 258-260, binne pp. 227-283). Matera (1996:73), sowel as Schnelle (2009:503), verwys net sydelings na liefde in hulle besprekings van die etiek van Lukas. 
In hierdie artikel word beoog om aan die hand van Lukas se gebruik van die woordgroepe wat potensieel met 'liefde'

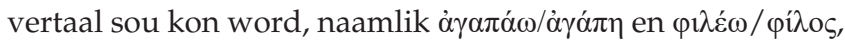
spesifiek op die intense liefde wat ons normaalweg met God, families of vriende assosieer, te fokus.

\section{'n Kort analise van die gebruik van die woordgroepe áparáw/ảyárn of $\phi \iota \lambda \varepsilon \dot{\varepsilon} \omega / \phi i ́ \lambda o s$ in Lukas}

Die gebruik van die twee woordgroepe ( $\dot{\alpha} \gamma \alpha \pi \alpha \dot{\omega} \omega / \dot{\alpha} \gamma \alpha \dot{\pi} \pi \eta$ en $\left.\varphi \imath \lambda \varepsilon \dot{\varepsilon} \omega / \varphi \dot{i} \varsigma_{0}\right)$ in Lukas blyk uit Tabel 1.

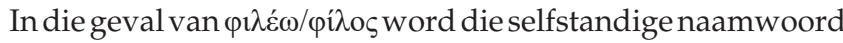
hoofsaaklik gebruik, terwyl die werkwoord domineer

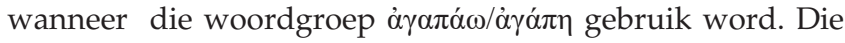
selfstandige naamwoord $\varphi$ í $\mathrm{o}_{\mathrm{o}}$, fokus hoofsaaklik op 'n sosiale posisie, naamlik van 'n vriend, terwyl die werkwoord $\alpha \gamma \alpha \pi \alpha ́ \omega$ op 'n aksie dui, naamlik om lief te hê. Dit suggereer 'n verskil in die semantiese fokus van die twee woordgroepe.

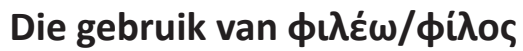

Die werkwoord $\varphi \imath \lambda \varepsilon \dot{\varepsilon} \omega$ kom maar twee maal in Lukas voor, naamlik in 20:46 $6^{4}$ waar die klem op voorkeur val of om van iets te hou (Danker, Bauer \& Arndt 2000:1056), byvoorbeeld voorkeur vir die beste plekke in die sinagoge. ${ }^{5}$ In 22:47 kry ons ' $n$ ander betekenis, naamlik om te soen (Judas soen vir Jesus). ${ }^{6}$ Die werkwoord word dus nie deur Lukas in die sin van aktiewe interpersoonlike liefde gebruik nie. Die selfstandige naamwoord, aan die ander kant, fokus in al die gebruiksgevalle op 'n antieke sosiale kategorie, naamlik vriendskap. ${ }^{7}$ In hierdie gevalle is die fokus op wat verwag word binne die raamwerk van vriendskap (waarin liefde wel 'n rol speel), maar nie op liefde as sodanig nie. Daarom word daar nie nou verder aandag aan hierdie gebruike gegee nie.

\section{Die gebruik van ảyaráw/ảyárn ${ }^{8}$}

Lukas gebruik die werkwoord $\dot{\alpha} \gamma \alpha \pi \alpha \omega^{9}$ semanties gevarieerd. ${ }^{10}$ Dit word gebruik om verskillende vlakke van persoonlike toegeneentheid of omgee te beskryf. In 11:43 dui dit byvoorbeeld bloot op voorkeur of 'hou van' (die Fariseërs

4.Alle verwysings waar slegs die hoofstuk en vers aangedui word, dui op Skrifgedeeltes uit die boek Lukas

5.In 11:43 word die woord $\alpha$ jүará $\omega$ in dieselfde betekenis gebruik, naamlik om van iets te hou (die beste stoele in die sinagoge). Dit is die enigste geval in Lukas waar die twee woordgroepe oorvleuel. Dit onderstreep die poreuse wyse waarop Lukas woorde gebruik.

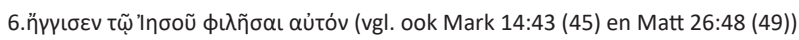

7.Vergelyk 7:6, 34; 11:5, 6, 8; 12:4; 14:10, 12; 15:6, 9, 29; 16:9; 21:16; 23:12. Hays (2010:53) merk op dat 'Luke draws heavily on friendship ideology in translating the ethical teachings of Jesus'.

8.Die selfstandige naamwoord áyárn word net een maal in 11:42 gebruik om na die liefde (van God) te verwys. Die betekenis van die woord word egter nie kontekstueel duidelik gemaak nie en is dus vir ons doeleindes nie van betekenisvolle hulp vir die bepaling van die betekenis van die woord nie (vgl. Marshall 1978:498).

אהב.9 [om lief te hê] word gewoonlik in die Septuaginta (LXX) met áyarów weergegee indien intense interpersoonlike verhoudings ter sprake is (Bovon 2005:236-237; vgl. ook Zimmermann 2007:546).

10.Die woord word nie in Handelinge gebruik nie.

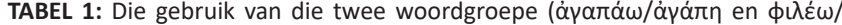
$\phi \dot{\lambda}$ oc) in Lukas.

\begin{tabular}{|c|c|c|c|}
\hline 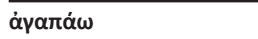 & 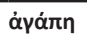 & 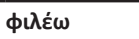 & Фіגоқ \\
\hline $\begin{array}{l}6: 27,32,35 ; 7: 5,42,47 \\
10: 27 ; 11: 42,43 ; 16: 13\end{array}$ & $11: 42$ & $20: 46 ; 22: 47$ & $\begin{array}{l}7: 6,34,11: 5,6,8 ; 12: 4 ; 14: 10 \\
12 ; 15: 6,9,29 ; 16: 9 ; 21: 16 ; 23: 12\end{array}$ \\
\hline
\end{tabular}

hou van die voorste plekke in die sinagoge). In 7:42, 47 val die fokus op dankbaarheid wat 'n positiewe houding veronderstel (hoewel vriendskap nie bedoel word nie). In 7:5 verdiep die intensiteit ietwat as daar gesê word dat 'n Romeinse offisier so baie van die Jode gehou het (hulle so liefhet) dat hy vir hulle 'n sinagoge laat bou het. ${ }^{11}$ Voorkeur in die sin van 'n positiewe ingesteldheid of, anders gestel, om meer van die een persoon (baas) as die ander te hou, word in 16:13 ${ }^{12}$ bespreek.

Daar is egter twee gevalle in Lukas (6:27-38 en 10:27-37) waar dit uit die betrokke kontekste blyk dat die toegeneentheid of liefde intens persoonlik is soos wat tussen familielede of vriende die geval is. Die fokus in hierdie artikel val op bogenoemde twee gevalle, veral omdat dit korrespondeer met die gebruik van liefde in, byvoorbeeld, die Johannesevangelie en -briewe waar Jesus telkens met diep persoonlike liefde geassosieer en God liefde genoem word. Is Lukas se Jesus ook so 'n 'Jesus van liefde'?

\section{Liefde vir jou vyand? (6:27-38) Die vloei en inhoud van die argument}

As deel van sy 'preek op die vlakte'13 ${ }^{\prime 13}$ gee Jesus sy dissipels drie maal die opdrag om hulle vyande lief te hê $(6: 27,32$, 35). ${ }^{14}$ Jesus se opdrag word goed gemotiveer deur wat volg. Hy begin deur die liefde vir die naaste te beskryf in terme van (1) om goed te doen, mense te seën of vir hulle te bid ten spyte van hulle haat of gevloek (6:27-28); en (2) om positief sonder wraak te reageer wanneer jy as gelowige met negatiewe of beledigende optrede gekonfronteer word (6:29-30). In 6:32-34 word die verwagting om beloon te word wanneer jy positief teenoor ander optree as norm vir Christelike gedrag afgekeur, terwyl liefdevolle gedrag waar niks terug verwag word nie, weer as Christelike norm gestel word. In 6:35 word hierdie Christelike norm gemotiveer. God tree so op teenoor alle mense en bowendien sal Hy sorg dat sy kinders vir hulle goeie dade beloon word. As kinders moet hulle die voorbeeld van hulle Vader $\operatorname{volg}(6: 36)$.

11. Hier is wel ' $n$ verhouding van voorkeur ter sprake, maar waarskynlik nie met dieselfde intensiteit as die intense verhouding tussen 'n vader en sy kind of God en sy kind nie. Louw en Nida (1996:300) beskryf een van die potensiële gebruike as 'to like, take pleasure in'

12. Die term liefde in 16:13 word alleen gebruik in die verduideliking waarom ' $n$ slaaf nie twee base op gelyke wyse kan dien nie. Die klem val nie hier op ' $n$ intieme persoonlike verhouding (soos met familie of vriende nie), maar eerder op voorkeur, diensbaarheid en lojaliteit. Benewens dit, is die bedoeling hier ook nie om die aard van die liefde vir God te beskryf nie, maar wat die diens aan God onderlê.

13.Vergelyk met Matteus 5:43-48 vir 'n korter weergawe van die Q-materiaal.

14.Bovon (2002:238-239) gee ' $n$ meer algemene beskrywing van wat liefde vir die vyand kan inhou. Popkes (2013:536) noem dat vyandsliefde as tema ook in Joodse dokumente voorkom, soos in T. Iss. 7:6, T. Zeb. 5:1, T. Naph. 8:3 (hierdie dokumente het hulle finale vorm in die tweede eeu n.C. aangeneem). Dus maak Popkes die volgende gevolgtrekking ' $[T$ The command to love one's enemies can be understood volgende gevolgtrekking 'TT]he command to love one's enemies can be understood
as an intensification of the contemporary ethic of love and should be traced back to as an intensific
Jesus himself.' 


\section{Wat hou liefde vir jou vyande in?}

In 6:27-30 word daar gefokus op hoe Christelike gedrag teenoor vyande (hier in die betekenis van 'opponente' [Edwards 2015:200; Green 1997:272], met ander woorde diegene wat nie Christene is nie) daar moet uitsien. Twee groepe voorbeelde word gegee:

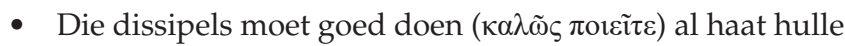
vyande hulle; hulle moet seën ( $\left(\varepsilon \dot{\lambda} \lambda \circ \gamma \varepsilon i \tau \varepsilon^{15}\right)$ al word hulle gevloek en hulle moet bid $(\pi \rho \circ \sigma \varepsilon v ́ \chi \varepsilon \sigma \theta \varepsilon)$ vir die vyand wat hulle vervloek. Liefde word hier beskryf as positiewe en pro-aktiewe gedrag wat nie op die houding en gedrag van die ander party fokus of daardeur beïnvloed word nie. In al drie gevalle lei die optrede van die gelowige tot positiewe gevolge vir die vyand (Green 1997:272).

- Die volgende drie voorbeelde gaan oor die verwagte optrede van die dissipels in gevalle waar daar negatief, lelik of onbillik teenoor hulle opgetree word deur hulle vyande (opponente), byvoorbeeld, om op die wang geslaan te word, om jou oorkleed te moet afgee, of om van jou eiendom te moet afstaan. Die reaksie van gelowiges moet konstant (selfs oordrewe) positief bly: hulle moet nie wraak neem of teëstand bied nie, maar moet meer doen as wat gevra word (vgl. Betz 1995:591-600; Scheffler 2006:94). Enige vorm van konflik word so, per definisie, vermy deur positiewe reaksies op negatiewe optredes.

Om op te som: die verwagte gedrag van die dissipels word dus beskryf in terme van positiewe, pro-aktiewe en liefdevolle aksies wat nie enige teken van wraak toon nie, ongeag die negatiewe optrede van die vyand. ${ }^{16}$

In die verse wat volg (6:32-34) verskuif die aandag na die vraag oor die waarde van resiproke gedrag - 'n sosiale konvensie wat baie tipies van antieke gemeenskappe was. ${ }^{17}$ Dit volg op die vraag wat uit 6:27-30 vloei, naamlik die redes waarom 'n mens goed moet doen aan mense wat jou kwaad aandoen. Die volgende verse (6:32-34) raak die kwessie aan deur 'n voorwaardelik retoriese vraag te stel: 'As julle net dié liefhet wat vir julle liefhet, watter aanspraak op dank $\left(\chi \alpha \alpha^{\prime} \varsigma^{18}\right)$ het julle dan nog?' Agter hierdie vraag lê tipiese antieke resiprositeitsdenke $^{19}$ (6:32), hoewel die nut daarvan hier

15.Danker et al (2000:480) beskryf die leksikografiese betekenis soos volg: 'to ask for bestowal of special favor, esp. of calling down God's gracious power' (vgl. ook Bovon 2002:236).

16.Die volgende Loeb-vertaling van Ps.-Libanus (Epistolary types 64) illustreer die belang van resiproke gedrag en hoe iemand wat dit nie doen nie, eintlik as vyand gesien word: 'You received many favors from us. Even I am therefore very amazed at how you do not remember any of these favors. You rather speak evil of us. This is typical of somebody who is extremely ungrateful. Ungrateful people do not care about good men and behave towards their benefactors as though they were about good
enemies.'

17. Resiprositeit is ' $n$ komplekse sosiale fenomeen wat die standaardgedrag van die antieke mens tot ' $n$ groot mate beïnvloed het (vgl. Kirk 2003:673). Die basiese gedagte agter resiprositeit is dat wat jy aan iemand anders gee deur daardie persoon in een of ander vorm aan jou teruggegee behoort te word. Dit was nie wetlik afdwingbaar nie, maar was 'n sterk sosiale verwagting (vgl. Trebilco 2019:505-506). Op hierdie manier is mense in gemeenskappe deur onderlinge verpligtings aan mekaar verbind. ' $n$ Motivering vir resiprositeit was dat 'what we do comes back to us, often with interest: "what goes around, comes around"' (Morgan 2007:42).

18.Vergelyk Kirk (2003:679) wat na Seneca se interpretasie van xápıs in resiproke kontekste verwys. Xápıc is gemik op 'those with the means to reciprocate' and 'with well-disposed intentions' (pp. 678, 682).

19.Bovon (2005:237-238) wys daarop dat resiprositeit die voorkeurverklaring vir hierdie voorbeelde is (vgl. ook Kirk 2003:682). bevraagteken word. Daar is niks spesiaals daaraan om diegene wat jou liefhet, terug lief te hê nie (dit wil sê in resiproke gedrag). Sulke resiproke gedrag was algemeen en verdien nie spesiale dank nie. Dit word bevestig deur twee voorbeelde wat uit die vorige gedeelte opgeneem word (6:27-30), naamlik om goed te doen en om gewillig te wees om jou goed vir ander te leen. Die punt wat hier gemaak word, is dat die gedrag van die dissipels, ook hulle liefde, nie deur die algemene resiproke verwagtings van die gemeenskap bepaal moet word nie (Nolland 1989:295, 298). Hulle het ander standaarde om na te streef.

Verskeie ondersoekers het opgemerk dat die woord $\alpha \gamma \alpha \pi \alpha ́ \omega$ hier as 'n oorkoepelende term funksioneer vir die verskillende vorms van gedrag wat in die gedeeltes genoem word.$^{20}$ In die drie verwysings na die verskillende vorms van gedrag word liefde vir die vyand elke keer eerste en volledig geformuleer (6:27-30 en dan 6:33-34 en 35), gevolg deur 'n 'lys' van die ander optredes - in die eerste geval ' $n$ volledige lys, en daarna 'n opsomming met net twee van die genoemde aksies uit die eerste lys. ${ }^{21}$ Die prioriteit van liefde in hierdie beskrywings, asook die opsommende weergawe van die ander aksies in die laaste twee gevalle (waarvan die twee voorbeelde in 6:33-34 en 35 die volledige lys in 6:27-30 generies weergee) blyk te suggereer dat liefde inderdaad oorkoepelend funksioneer. Dit ondersteun die siening dat die voorbeelde van gedrag (6:27-30) inderdaad 'n uitdrukking is van wat liefde behels.

In 6:35 word die opdrag om jou vyande lief te hê 'n derde maal herhaal met dieselfde opsomming (twee voorbeelde) as in die voorafgaande opdrag, naamlik om goed te doen en om gewillig te wees om aan ander te leen. Daarmee word 'n kernvereiste vir die gedrag van die dissipels bevestig: hulle moet niks terugverwag wanneer hulle goed doen aan hulle vyande nie; met ander woorde, alle verwagtings wat resiprositeit meskien kan skep, word 'gekanselleer'. Dissipels moet eenvoudig goed doen en op 'n positiewe manier optree, ongeag wat die reaksie van ander daarop is. Green (1997:273) merk in die verband op: 'others are to be treated lovingly, period, without thought to reciprocating behaviour'. 'n Gemeenskap word dus in die vooruitsig gestel wat weier 'to treat others ... as though they were enemies' en verplaas so eksklusiwiteit met inklusiwiteit. ${ }^{22}$ Maar waarom?

20.Nolland (1989:294) merk op: " "Do good" indicates the active tenor of the love called for. The calls to "bless" and "pray for" intensify the demand for love of the enemy...'. Bovon (2005:237) meen ewe-eens: "Luke interprets the first example with the second: "to love" thus means a concrete and active attitude, which one can translat as "to do good". Gowler (2016:58) vergelyk die vader se aksies in die gelykenis van die verlore seun met tipiese liefde. Sam (2008:xv) meen weer dat 'Luke's portrait of Jesus is that of a human filled with love' en dit word 'throughout Lukan narratives' aangetref. In sy bespreking van liefde en rykdom bespreek hy byvoorbeeld Lukas 4:16-30; 7:11-17; 12:49-59; 17:11-19; 19:1-10; 22:35-38 wat illustreer hoe breed hy die konsep van liefde in Lukas verstaan (vgl. ook Scheffler 2006:82).

21.In 6:27-28 word die trilogie van om goed te doen; om mense wat jou kwaad aandoen te seën; en ook vir hulle te bid, genoem. Die drie aksies word in verse 33 en 35 onder die een noemer saamgevat, naamlik 'om goed te doen'. Net so is daar die trilogie in 6:29-30, naamlik die klap op die wang; om die bokleed te eis; en om jou besittings te eis. Die drie word weer in vers 34 saamgevat as 'om jou besittings te vat of te leen'.

22.Schnelle (2009:503) is korrek met sy opmerking: 'Luke indeed "rejects the ethic of mutuality structured according to how others respond".' Green (1997:270-272) mutuality structured according to how in hierdie gedeelte eis dat sy dissipels almal sal behandel soos suggereer dat Jesus in hierdie gedeelte eis dat sy dissipels almal sal behandel soos
familie en vriende, terwyl Nolland (1989:296) meen dat die vyand behandel moet word volgens die 'highest demands group solidarity might impose'. 
In 6:35-36 word drie redes genoem as motivering vir hierdie tipe gedrag, naamlik: (1) 'n groot beloning wag; (2) om kinders van die Allerhoogste te wees (te word $-\tilde{\varepsilon} \sigma \varepsilon \sigma \theta \varepsilon$ vioì v́í⿴囗十v); en (3) die verwagting dat 'n kind soos sy pa moet optree.

Resiprositeit is duidelik tot nou toe verwerp as rede vir vyandsliefde. In 6:35 word egter gesê, 'Sonder om iets terug te verwag, moet julle julle vyande liefhê en goed doen en uitleen. Dan sal daar vir julle 'n groot beloning wees.' Wat hier geïmpliseer word, is dat die dissipels nie van mense iets terug moet verwag nie (d.w.s. resiproke gedrag moenie hier funksioneer nie), maar dat hulle wel van God 'n groot beloning sal kry. Hulle kan dus wel iets terugverwag vir die liefde wat hulle aan ander betoon. Aangesien die essensie van resiprositeit is om iets terug te verwag wanneer jy aan ander goed gedoen het, argumenteer sommige geleerdes dus dat hier tog van 'n tipe resiprositeit sprake is in die sin dat God en nie die mense nie, die goeie dade van gelowiges 'terugbetaal' (beloon). Daar word gemeen dat dit 'n tipe 'verwysde resiprositeit' is, naamlik A gee vir B en B gee vir C. Hierdie vorm van 'verwysde resiprositeit' (univocal reciprocity) is tipies van antieke resiproke verhoudings ${ }^{23}$ en word in Johannes sowel as Paulus se geskrifte aangetref. ${ }^{24}$ Gelowiges (A) gee vir hulle vyande (B) en sal niks direk van hulle terugkry nie, maar hulle (A) sal wel van God (C) die nodige (en meer) terugontvang. In die lig hiervan en in 'n konteks waar dit ten diepste oor resiprositeit gaan, is dit goedskiks moontlik dat die 'groot beloning' $(\mu 1 \sigma \theta \text { òs) })^{25}$ 'n resiproke aksie van God veronderstel.

In 6:35 word familiale taal ook tot die argument toegevoeg, naamlik om kinders van God te wees (te word). God word hulle 'Vader' genoem (6:36; vgl. ook Matt 5:43-48; Edwards 2015:201-202). Daar is in die antieke tyd aangeneem dat kinders op 'n resiproke manier teenoor hulle ouers moes optree uit dankbaarheid vir hulle geboorte en hulle versorging daarna. Die resiprositeit hou in dat hulle weer van hulle kant hulle ouers sou gehoorsaam en versorg wanneer hulle oud word. Die tipe familiale gehoorsaamheid hou in dat kinders (seuns) volgens die voorbeeld van hulle vaders sou optree. Die vader was die primêre rolmodel vir die kind wat ook 'n antieke gebruik, naamlik mimesis ${ }^{26}$ veronderstel het.

In Grieks-Romeinse en selfs Hellenisties-Joodse kontekste was mimesis 'n belangrike motivering vir gedrag en was dit tipies deel van die onderwyssisteem - ook binne families. Dit verwys na die 'na-aap' van die gedrag van 'n rolmodel, 'n

23.Seaford (1998:2) beskryf "univocal reciprocity' as 'A's benefit to B causes B to benefit $C$, and thereby $C$ to benefit $A$ (or $D$ etc., with $A$ benefitting eventually)' Wanneer persone op ongelyke (finansiële of sosiale) vlakke is, mag die manie waarop die een vir die ander 'teruggee', verskil. Byvoorbeeld, as die ryke vir die arme kos gee mag die arme vir die ryke in eer terugbetaal deur hom in die openbaar te prys vir sy daad.

24.In 1 Johannes 3:7-5:3 word God se liefde deur gelowiges 'teruggegee' deur dit aan die medegelowiges te gee (A-B, B-C) (vgl. Trebilco 2019:498-516). In Filippense 4:18-19 word die gawe van die gemeente aan Paulus deur Paulus as 'n gawe aan God gesien. Resiprositeit kan dan van God verwag word (vgl. ook Luk 14:14).

25.Green (1997:273-274) suggereer dit ook, maar noem dit resiprositeit in 'n 'radicalized form' (vgl. ook Marshall 1978:262; Joubert 1999:50-63).

26.Vergelyk Bennema (2014:261-274) vir'n gedetailleerde bespreking van mimesis. outoritatiewe figuur ${ }^{27}$ wat die voorbeeld vir behoorlike gedrag stel wat dan nagevolg moet word. Mimesis beteken nie meganiese navolging (om die presiese aksies uit te voer wat die pa uitgevoer het) nie, maar beoog eerder om die aard en karakter van die optrede in nuwe situasies gestalte te gee. As die pa byvoorbeeld in oorlog dapper was deur 'n swaard te gebruik, moet die dapperheid en nie noodwendig die gebruik van die swaard nie, in nuwe situasies gestalte gegee word.

Hierdie eienskap is onderliggend aan die opmerking in 6:35-36 dat die dissipels liefdevol teenoor hulle vyande moet optree: '[O]mdat (ő $\tau$ [redegewend]) Hy (God die Vader) self goed $\left(\chi \rho \eta \sigma \tau \delta^{28} \varsigma^{28}\right.$ is vir die ondankbares en slegtes. Wees barmhartig soos julle Vader barmhartig is.'

Dit is 'n ekstra motivering vir dissipels om hulle vyande lief te hê - God se kinders moet soos hulle Vader wat hulle rolmodel is en nagevolg moet word, optree. ${ }^{29} \mathrm{Hy}$ is goed en barmhartig teenoor diegene wat ondankbaar en sleg is. So moet hulle ook optree teenoor diegene wat ondankbaar en sleg is, onder meer hulle vyande (Scheffler 2006:83).

Dit is dus duidelik dat die kombinasie tussen mimesis en resiprositeit die gedrag van die dissipels teenoor hulle vyande motiveer en so in 'n nuwe lig plaas. Dit gaan oor gedrag van die kinders van God binne die raamwerk van die familie van God. Hulle gedrag word dus inderdaad deur God se eie optrede van barmhartigheid geïnspireer (Green 1997:272).

Daar is geleerdes wat egter skepties is dat dit hier oor resiprositeit gaan, veral voordat die invloedryke artikel van Kirk (2003) verskyn het. ${ }^{30}$ Eerstens word daar geargumenteer

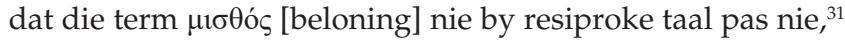
aangesien dit 'n tipe betaling veronderstel vir werk wat gedoen is.

'n Argument wat teen die beswaar aangevoer word, is dat die term ook gebruik kan word om te verwys na 'recognition (mostly by God) for the moral quality of an action, recompense' (Danker et al. 2000:653), of 'recompense based upon what a person has earned and thus deserves' (Louw \& Nida 1996:490). Hierdie betekenis lê na aan die bedoeling van resiprositeit en sluit nie uit dat die woord in 'n konteks gebruik kan word wat resiprositeit veronderstel nie. In Matteus 6:1-5, 16 (vgl. ook 1 Kor 9:17-18; 2 Klem 3:3), waar $\mu 1 \sigma \theta$ ó ook gebruik word, onderlê resiprositeit duidelik die argument. Daar voer

27 Plinius (Letter 8.13 - Loeb), byvoorbeeld, erken die waarde van 'n persoonlike 'model', soos jou pa: '... he whom nature designed you should most resemble is, of all others, the person whom you should most imitate'.

28 Danker et al. (2000:1090) dui die leksikografiese betekenis onder meer aan as 'to be kind, loving, benevolent'.

29 Bock (1996:604) merk op: 'the disciples are to imitate their heavenly Father. God's character is the guide for our character'. Green (1997:275) erken ook dat dit nie hier om resiprositeit gaan nie, maar om 'imitation of God' (vgl. ook Marshall 1978:264).

30 Hoewel die artikel van Van Unnik (1966:284-300) vroeër verskyn het, het dit nie dieselfde wye ontvangs as die artikel van Kirk en latere publikasies geniet nie.

31 Volgens Danker et al. (2000:65) is die leksikografiese potensiaal van $\mu$ toӨó onder meer die volgende: 'remuneration for work done' of 'recognition (mostly by God) for the moral quality of an action, recompense'. Louw en Nida (1996:490) formuleer dit weer so: 'a recompense based upon what a person has earned and thus deserves'. 
mense religieuse aksies uit om deur ander gesien te word en so as resiproke beloning eer te ontvang. Dus, die resiproke gebruik van $\mu 1 \sigma \theta$ ó $\varsigma$ in 6:35 is goedskiks moontlik en verswak die besware teen die resiproke gebruik hier.

'n Verdere argument wat hier teen die resiproke gebruik geopper word, is dat resiprositeit gewoonlik tussen mense funksioneer wat dan dienooreenkomstig op ekwivalente manier kan reageer. Die gedagte van 'n groot ( $\pi \mathrm{o} \lambda v \varsigma)$ beloning sou dan nie met die idee korrespondeer dat daar op vergelykbare vlak 'teruggegee' word nie.

Ook hierdie argument is nie so oortuigend as wat op die oog af mag blyk nie. Eskatologiese belonings (wat natuurlik goddelike belonings is en daarom altyd meer en groter is as wat menslik moontlik is) is algemeen in Christelik-Joodse tradisies. Gewoonlik word ook nie net een handeling beloon nie, maar 'n lewenswyse met meerdere optredes soos wat in Lukas 6 ook gesuggereer word. Om regverdig te lewe (as lewenstyl) word nie daad vir daad beloon nie, maar kulminatief by die wederkoms as eskatologiese beloning. ${ }^{32}$ Dit verswak die argument dat die verwysing na 'n groot beloning resiprositeit uitskakel, want God se 'terugbetaling' (resiprositeit) is in elk geval hemels en goddelik; met ander woorde, groter as wat die mens kan gee. Hier beloon hy die lewenswyse (liefde vir die vyande) van sy kind met 'n groot eskatologiese gawe wat binne die konteks nie resiprositeit as motivering uitskakel nie. Gelowiges moet dus nie van hulle vyande resiproke gedrag verwag nie en dit moet ook nie hulle gedrag teenoor die vyande beïnvloed nie. God sal wel die resiproke verwagtinge met oorvloed vervul.

Wanneer die argumente geweeg word, blyk dit tog dat die antieke gebruike om gedrag te motiveer, naamlik resiprositeit en mimesis, inderdaad in die konteks 'n sterk rol speel om liefde vir die vyand te motiveer. Christelike gedrag word in terme van openheid gedefinieer in woord sowel as daad teenoor ander sonder om enigiets van die ander persoon terug te verwag, aangesien alle verwagtings op God gevestig is (Joubert 2001:26-37). Die rede en motivering vir sulke gedrag is op God se gesindheid en optrede teenoor almal, ook die ondankbares en slegtes, gebaseer. God se kinders moet die voorbeeld van God, as hul Vader en rolmodel, volg.

Dit bring ons by die vraag: Wat is die semantiese skopus en diepte van die konsep 'liefde' in hierdie konteks? Soos reeds aangetoon, gebruik Lukas die woord $\alpha \gamma \alpha \pi \alpha ́ \omega$ op ander plekke om na verhoudings met laer semantiese intensiteit te verwys (soos om bloot van iets te hou of om iets te verkies). Wat presies is die semantiese intensiteit van die woord liefde as dit by vyandsliefde kom?

Die semantiese intensiteit van die woord liefde in hierdie gedeelte is kompleks. Aan die een kant word daar nie 'n diep en wedersydse persoonlike verhouding tussen dissipel en vyand veronderstel soos wat daar tussen familie of vriende verwag is nie, want die verhouding is nie wederkerig nie.
Die vyande reageer immers glad nie terug nie en toon vyandigheid wanneer hulle kontak met die dissipels het goedheid en liefde word nie hier wedersyds beleef nie. Met ander woorde, die vyande wat liefde van die dissipels ontvang, bly met hulle negatiewe gedrag vyande. Liefdevolle gedrag word as eensydig beskryf: komende van die dissipels alleen.

Aan die ander kant, bewys die dissipels liefde wat impliseer dat hulle goedheid en gawes wel die potensiaal, klimaat en verwagting by hulle vyande kan skep om resiprook te reageer (al is dit maar net 'n moontlikheid). Die vyande was immers ook kinders van hulle tyd wat geweet het hoe resiprositeit werk en die druk van hierdie sosiale verwagtings ervaar het. Indien hulle dus miskien wel sou toegee aan die verwagtings sou interpersoonlike verhoudings tussen hulle en die gelowiges die resultaat kon wees wat selfs in vriendskap sou kon ontwikkel: 'n persoon doen goed aan sy vriende en maak vriende daardeur. In die geval van die vyande is dit moontlik dat resiproke verwagtings nie totaal vermors is nie, maar dat dit tog implisiet in die agtergrond 'n rol gespeel het deurdat dit die vyande moontlik kon beïnvloed om deel van Jesus se groep te word.

Indien bogenoemde verklaring korrek is, beteken dit dat die semantiese skopus van die woord liefde wat die intensiteit daarvan betref, ongedefinieerd bly. Die liefde van die dissipels vir hulle vyande, in navolging van die liefde van hulle Vader vir die slegtes en ondankbares, word deur barmhartigheid en goedheid gekenmerk wat intensiewe persoonlike toegeneentheid en betrokkenheid vir die ander party veronderstel soos ' $n$ mens inderdaad van familie of vriende sou kon verwag. Hierdie vlak van betrokkenheid, soos reeds genoem, kom (nog) nie van albei kante nie, soos uit die negatiewe optrede van die vyande blyk. Dit beteken dat die gelowiges nie balans in die verhouding deur resiproke gedrag moet verwag of soek nie. Die onderliggende hoop (gebaseer op die bestaande sosiale resiproke verwagtings vgl. ook 6:31) is dat hulle gedrag tog tot nuwe en meer soliede sosiale bindings tussen hulle en hulle vyande sou kon lei. ${ }^{33}$ As die vyande tog resiprook reageer, sal dit natuurlik die tipe liefde verander van eensydige na wedersyde liefde en tot hegter sosiale binding lei. Kirk (2003:682) meen dat dit hier gaan oor 'liberal acts of general reciprocity, not the abandonment of reciprocity in principle'. Op hierdie manier motiveer resiprositeit eintlik alle gedrag.

\section{Jy moet God en jou naaste liefhê (10:25-37)}

Die woord $\dot{\alpha} \gamma \alpha \pi \alpha \dot{\alpha}$ [liefde] kom ook voor in Jesus se gesprek met die skrifgeleerde oor die liefdesgebod in 10:25-37. Die skrifgeleerde se vraag gaan nie oor watter gebod die grootste is nie (vgl. die parallelle dele in Markus en Matteus), ${ }^{34}$ maar oor wat ' $n$ mens moet doen om die ewige lewe te ontvang; met ander woorde om deel van God se eskatologiese reddingsplan te word. Tipies van antieke Joodse

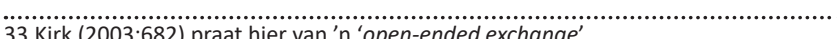
open-ended exchange

34.Nolland (1993:583) merk op dat hierdie gebooie in Lukas as eenheid gesien word. In Markus (en Matteus) word die vraag gevra watter van die twee gebooie die grootste is; met ander woorde, die fokus val op die tegniese vraag hoe gebooie geëvalueer word (vgl. Popkes 2013:536-537; Bock 1996:1026). 
'Streitgesprächen' reageer Jesus op die vraag met 'n teenvraag, naamlik wat die skrifgeleerde oor die saak dink en waarop die skrifgeleerde die dubbele liefdesgebod aanhaal (10:27). Dit is belangrik om hier daarop te let dat nie Jesus nie, maar die skrifgeleerde die liefdesgebod aanhaal (anders as in Markus en Matteus (vgl. Burridge 2007:258; Furnish 1972:34-38; Marshall 1978:440; Nolland 1993:583, 596). Dit impliseer dat dit volgens Joodse siening die gangbare antwoord was (Dt 6:5; Lv 19:18). ${ }^{35}$ Jesus stem hiermee saam en dit beantwoord die skrifgeleerde se eerste vraag. Hy vra egter 'n verdere vraag (10:29) wat oor 'n kontensieuse tegniese punt gaan, naamlik wie presies as 'naaste' ( $\pi \lambda \eta \sigma i ́ o v)$ kwalifiseer aan wie dan liefde betoon moet word. ${ }^{36}$

Vir die doeleindes van hierdie artikel hoef die gelykenis wat Jesus vertel nie in detail bespreek te word nie. Wat wel van belang is en as beginpunt kan dien, is Jesus se vraag wat op die gelykenis volg, naamlik: 'Wie van hierdie drie is volgens jou (die skrifgeleerde) die naaste van hom wat onder die rowers verval het?' (10:36). Hier word die konsep naaste gedefinieer vanuit die posisie van die man in nood; met ander woorde, wie was die naaste van die beseerde man? Vanselfsprekend die persoon wat aan hom barmhartigheid betoon, ongeag enige sosiale, etniese of kulturele taboes. Op hierdie wyse word die Joodse skrifgeleerde in die posisie van die beseerde man in die verhaal geplaas en het hy dus geen ander keuse as om met 'Die man wat aan hom medelye bewys het' (die Samaritaan) (10:37) te identifiseer as sy naaste ${ }^{37}$ nie. Hy moes noodgedwonge erken dat 'n Samaritaan ook sy naaste kan wees, al is dit 'n opvatting wat nie eintlik binne Joodse tradisie goedkeuring weggedra het nie. ${ }^{38} \mathrm{Op}$ hierdie manier word die 'naaste' geïdentifiseer as die persoon in nood wat jou pad kruis, ongeag wie dit is en sonder enige vooroordele. Nie etniese, sosiale of kulturele verwantskap maak iemand jou naaste nie. Nee, 'it is the practice of mercy that makes a passer-by into a neighbour', soos Nolland (1993:596) inderdaad aantoon (vgl. Bock 1996:1034-1035; Marshall 1978:450). So vind 'n ommekeer van verwagting en verantwoordelikheid plaas en die skopus van liefde word uitgebrei, selfs tot by die mense wat as jou vyande beskou kan word (vgl. Scheffler 2006:85; Tannehill 1996:537). Dit bevestig die universele perspektief wat so eie aan Lukas is.

Die verband tussen twee opmerkings in 10:25-28 en 10:29-37, ${ }^{39}$ moet op gelet word wanneer die betekenis van liefde in Lukas ter sprake kom. In albei gevalle merk Jesus op: 'Maak so/doen dit' (10:28, 37). In 10:27-28 word gesê dat

35.Zimmermann (2007:542) wy daarop dat die dubbele liefdesgebod nie onbekend was onder die Jode nie. Veral in die Testament van die Twaalf Patriarge word dit genoem, byvoorbeeld in Test/ss 5:2, 7.6; TestSeb 5:1; TestDan 5:3; TestBen 3:1-3 (vgl. ook Jub 36.4-8; Filo, Spesiale Wette 2.15, 63; Tannehill 1996:181-182; Evans (990:178; Bock 1996:1026).

36.Vir die skrifgeleerde was dit vanselfsprekend dat die 'naaste' ' $n$ volksgenoot moes wees, ' $n$ lid van die verbondsvolk van God wat die Samaritane uitgesluit het, soos Zimmermann (2007:547) ook aandui. Hy wys verder op gedeeltes (Lev 19:34, Deut 10:19, Arist. 227, Filo Virt. 51ff.) waar vreemdelinge of selfs vyande objekte van liefde is, hoewel hulle nie 'naastes' genoem word nie.

37.Zimmermann (2007:543) verwys in hierdie geval na metaforiese interaksie.

38.Kyk Zimmermann (2007:545) vir refleksie oor die posisie van die Samaritane (vgl. ook Marshall 1978:450; Nolland 1993:583; Tannehill 1996:183-184; Sam 2008:14).

39.Marshall $(1978: 440,445)$ argumenteer sterk vir die eenheid van die twee dele (vgl. ook Nolland 1993:596; Bock 1996:1034). mens jou naaste moet liefhê ( $\dot{\alpha} \gamma \alpha \pi \alpha ́ \omega)$ soos jouself en in 10:37

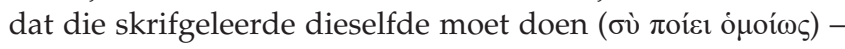
natuurlik met verwysing na die barmhartige ( $\varepsilon^{\prime} \lambda \varepsilon \circ \varsigma$ - om toegeneentheid te betoon en aan ander goed te doen) (Danker et al 2000: ad loc.) optrede van die Samaritaan. In die narratief word die vereistes van die Wet en die barmhartige optrede van die Samaritaan verweef. Liefde word in terme van barmhartigheid beskryf. Om te doen wat die Wet vra, impliseer om jou naaste wat enigiemand kan wees wat jou barmhartigheid en goedheid nodig het, selfs 'n Samaritaan, lief te hê. ${ }^{40}$

Die semantiese intensiteit van liefde word dus gedefinieer in terme van die bereidwilligheid tot goedheid en barmhartigheid ongeag wie dit is en wat dit van jou vra (10:33). Dit is 'the compassionate serving of whoever stands in need' (Furnish 1972:89-90). ${ }^{41}$ sonder resiproke verwagtings soos uit die gelykenis blyk (10:33-35). Deurdat die Joodse skrifgeleerde self die liefdesgebod formuleer (10:27), word die intensiteit van die liefde in die konteks verbind met die intense liefde wat Jode onder mekaar as verbondsvolk van God moet betoon. Dit eggo die liefde wat familielede onder mekaar moet hê, aangesien die Joodse familie as kern van die breër gemeenskap gesien is. Wat vir die familie geld, moet ook in die breër gemeenskap geld. Dit veronderstel 'n hoë intensiteit van liefde, wat eie aan familie en vriende is, en waar die bereidheid om te help en om toegeneentheid aan elkeen te bewys sonder dat enige voorbehoud of voorwaardes voorop gestaan het.

Daar is ook treffende ooreenkomste tussen 10:25-37 en 6:27-36. ${ }^{42}$ Van belang is dat in 6:35-36 die dissipels gevra word om hulle vyande lief te hê en barmhartig (oíкíp $\mu \omega v$ ) teenoor hulle te wees soos hulle Vader barmhartig en goed teenoor die slegtes en ondankbares is. Liefde en barmhartigheid word nou genetwerk. Dit is ook die geval in 10:25-36 met die verskil dat die woord č $\lambda \varepsilon \varsigma_{\text {in }}$ in plaas van оiктíp $\mu \omega v$ hier gebruik word. Die twee woorde is semanties nou verwant en toon weinig verskil in betekenis. Louw and Nida (1996:750) kategoriseer albei in dieselfde semantiese veld ('moral and ethical qualities and related behaviour', en Louw en Nida (1996:750) sowel as Danker et al. (2000:361, 700) gebruik woorde soos 'mercy' en 'compassion' om albei woorde mee te beskryf.

\section{Samevattende konklusie}

Die doel van hierdie artikel is om die gebruik en semantiek

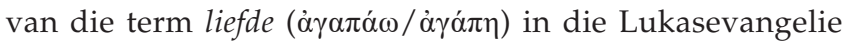
te bepaal. Die woord $\alpha \gamma \alpha \pi \alpha ́ \omega$ word inderdaad met 40. Popkes (2013:536) neem aan dat the synoptic versions agree that the love command of Jesus concerns not only one's immediate dependents and peers but also, and indeed primarily, socially marginalized people, including foreigners and even one's enemies'. Hy (Popkes 2013:538) merk verder op dat 'Luke wants to initiate a Christian ethos in which Jesus' followers are prepared to give their existing assets for the support of people in need of help and care' (vgl. ook Nolland 1993.596-598; Bock 1996:1034-1035; Fitzmyer 1981-1985:883-887; Marshall 1978:446).

41.Zimmermann (2007:547) meen dat liefde en barmhartigheid nie natuurlike bedmaats was in die tyd waarin Lukas geskryf is nie. Dit kom volgens hom nie in die Eerste Testament voor nie, maar wel later in die Testament van die Twaalf Patriarge.

42.Vgl. Scheffler (2006:84). Hy meen ook dat die gelykenis van die Samaritaan 'illustrates pictorially what is argued in the passage on love for the enemy' (p. 86). 
verskillende semantiese nuanses gebruik wat in intensiteit van mekaar verskil. Dit onderstreep dat die woord nie as tegniese term gebruik word nie; met ander woorde, dit het nie 'n enkele vaste betekenis nie. Die term word ook nie in die Lukasevangelie as interne identiteitsmerker vir Lukaanse Christene ontwikkel soos wat in die Johannesevangelie die geval is nie (vgl. Joh 13:35-36). Die term verwys ook alleen maar in twee kontekste (6:27-36 en 10:25-37) na 'n intieme persoonlike toegeneentheid soos wat binne die sosiale ruimtes van familie en vriende verwag is.

Die omvattendste bespreking van 'liefde' ( $\dot{\alpha} \gamma \alpha \pi \alpha \dot{\omega})$ word in 6:27-38 aangetref waar gelowiges tot vyandsliefde aangespoor word. Liefde funksioneer hier as oorkoepelende term vir die ander terme wat vir barmhartigheid en goeie optrede in hierdie konteks gebruik word. Geen weerwraak word voorgestaan indien gelowiges sleg behandel word nie, maar wel 'n reaksie van goedheid en toegeneentheid wat meer gee as wat gevra word. 'n Soortgelyke patroon word in 10:25-37 aangetref: liefde word uitgedruk in terme van die barmhartige optrede van die Samaritaan.

Dit strook met die algemene boodskap van Lukas. Lukas se belang lê hoofsaaklik by die barmhartige optrede teenoor die sogenaamde onderdruktes ('underdogs') in die samelewing. Lukas lê klem op die belang en versorging van die armes, die korrekte houding teenoor rykdom en mag, die belang van vroue, ensovoorts. In hierdie 'wolk van konsepte en verskillende terme' kom die woord liefde selde voor, soos in Tabel 1 aangetoon het. Afgesien daarvan spandeer Hays (2010), byvoorbeeld, 270 bladsye aan die bespreking van die probleem van rykdom en maar net omtrent 20 bladsye aan die konsep van liefde (vgl. ook Roth 1997:142-206). Beteken hierdie terughoudendheid teenoor die gebruik van die woord liefde $(\dot{\alpha} \gamma \alpha \pi \alpha \omega \omega)$ dat die Jesus soos deur Lukas beskryf eintlik nie in liefde belangstel nie en dit alleen maar 'n voetnoot tot die geheel van sy boodskap is? Is Jesus hier nie 'n 'Jesus van liefde' nie?

Dit blyk bloot op die oog af asof liefde net 'n voetnoot kan wees, maar as die argument hierbo geldig is, beteken dit dat liefde deur Lukas hoogs waarskynlik as oorkoepelende term direk met konsepte soos barmhartigheid, hulp, toegeneentheid, die doen van wat goed is, om nie wraak te koester nie, om nie net mense te help vir eie gewin nie, ensovoorts, verbind word. Daar is immers hierbo geargumenteer dat die barmhartige optrede van die Samaritaan eintlik liefde in aksie beteken wat net geldig is van die voorbeelde wat in die gedeelte oor vyandsliefde genoem word. Dit sou beteken dat die verskillende terme in die Lukaanse etiek van toegeneentheid teenoor die onderdruktes, armes, vroue, en so meer, onder die sambreel van liefde tuisgebring kan word. Die totale som van al hierdie beskrywings van vorms van goeie optrede is illustrasies van wat liefde is. So neem liefde verskillende vorms aan, maar beteken dit veral om onvoorwaardelike barmhartigheid en toegeneentheid aan mense in nood te bewys (vgl. Burridge 2007:260; Furnish 1972:89).

Om met die vraag waarmee begin is, af te sluit: Is Lukas se Jesus 'n 'Jesus van liefde'?, blyk die antwoord 'n voorwaardelike 'ja' te wees. Voorwaardelik 'ja' in die sin dat die term self nie met hoë frekwensie gebruik word nie en daarmee saam dat die woord waarskynlik oorkoepelend gebruik word vir die rykdom van Lukaanse beskrywings en voorskrifte rondom barmhartigheid, onvoorwaardelike goedheid wat aan mense in nood bewys moet word; natuurlik ongeag hulle reaksie op hierdie liefde.

\section{Erkenning Mededingende belange}

Die outeur verklaar dat daar geen finansiële of persoonlike verbintenis is met enige party wat hom nadelig kon beïnloed het in die skryf van hierdie artikel nie.

\section{Outersbydrae}

J.v.d.W. was die enigste outeur betrokke by die skryf van die artikel.

\section{Etiese oorwegings}

Hierdie artikel volg alle etiese standaarde vir navorsing.

\section{Befondsing}

Hierdie navorsing het geen spesifieke toekenning ontvang van enige befondsingsagentskap in die openbare, kommersiële of nie-winsgewende sektore.

\section{Databeskikbaarheid}

Die outeur bevestig dat die data wat die bevindinge van hierdie studie ondersteun, beskikbaar is in die artikel.

\section{Vrywaring}

Die sienings en menings wat in hierdie artikel uitgedruk word, is dié van die outeur en weerspieël nie noodwendig die amptelike beleid of posisie van enige geaffilieerde verwantskap van die outeur nie.

\section{Literatuurverwysings}

Danker, F.G., Bauer, W. \& Arndt, W.F., 2000, A Greek-English lexicon of the New Testament and other early Christian literature, University of Chicago Press, Chicago, IL.

Bennema, C., 2014, 'Mimesis in John 13. Cloning or creative articulation?', NT 56(3), 261-274. https://doi.org/10.1163/15685365-12341465

Betz, H.D., 1995, Sermon on the mount: A commentary on the Sermon on the Mount including the Sermon on the Plain, Fortress, Minneapolis, MN.

Bock, D.L., 1996, Luke: 9:51-24:53, vol. 2, Grand Rapids: Baker Academic. (Baker Exegetical Commentary on the New Testament).

Bovon, F., 2005, Luke the theologian's fifty-five years of research (1950-2005), Baylor University Press, Waco, TX.

Burridge, R.A., 2007, Imitating Jesus. An inclusive approach to New Testament ethics, Eerdmans, Grand Rapids, MI.

Edwards, J.R., 2015, The Gospel according to Luke, Eerdmans, Grand Rapids, MI. (Pillar NT Commentary). 
Evans, C.A., 1990, Luke, Baker Books, Grand Rapids, MI. (Understanding the Bible Commentary Series).

Fitzmyer, J.A., 1981-1985, The Gospel according to Luke, 2 vols, Doubleday, Garden City, NY.

Furnish, V.P., 1972, The love commandment in the New Testament, Abingdon, Nashville, TN

Gowler, D.B., 2016, 'The characterization of the two brothers in the parable of the prodigal son (Luke 15:11-32): Their function and afterlives', in F. Dicken \& J. Snyder (eds.), Characters and characterization in Luke-Acts, pp. 55-72, London, T\&T Clark.

Green, J.B., 1997, The Gospel of Luke, Eerdmans, Grand Rapids, MI.

Green, J.B., 2013, 'Luke, Gospel of', in J.B. Green (ed.), Dictionary of Jesus and the Gospels, vol. 2, pp. 540-552, InterVarsity Press, Downers Grove, IL.

Hays, C.M., 2010, Luke's wealth ethics. A study in their coherence and character, Mohr Siebeck, Tübingen. (WUNT 2)

Hays, R.B., 1996, The moral vision of the New Testament. A contemporary introduction to New Testament ethics, Harper, San Francisco, CA.

Holladay, C.R., 2005, A critical introduction to the New Testament. Interpreting the message and meaning of Jesus Christ, Abingdon Press, Nashville, TN.

Joubert, S.J., 1999, 'Religious reciprocity in 2 Corinthians 9:6-15: Generosity and gratitude as legitimate responses to the "charis tou theou"', Neotestamentica 33(1), 50-63. https://doi.org/10.1177/014610790103100104

Joubert, S.J., 2001, 'One form of social exchange or two? "Euergetism," patronage, and Testament studies', Biblical Theology Bulletin 31(1), 26-37.

Kirk, A., 2003, 'Love your enemies, the golden rule, and ancient reciprocity (Luke 6:27-35)', JBL 122(4), 667-686. https://doi.org/10.2307/3268071

Louw, J.P. \& Nida, E.A., 1996, Greek-English lexicon of the New Testament: Based on semantic domains, United Bible Societies, New York, NY.

Marshall, I.H., 1978, The Gospel of Luke: A commentary on the Greek Text, Paternoste Press, Exeter. (New International Greek Testament Commentary).

Matera, F.J., 1996, New Testament ethics: The legacies of Jesus and Paul, Westminste John Knox Press, Louisville, KY.
Morgan, T., 2007, Popular morality in the Early Roman Empire, Cambridge, CUP.

Nolland, J., 1989, Luke 1:1-9:20, Word, Incorporated, Dallas, TX. (Word Biblical Commentary 35A)

Nolland, J., 1993, Luke 9:21-18:34, Word, Incorporated, Dallas, TX. Word Biblica Commentary 35B)

Popkes, E.E., 2013, 'Love, love command', in J.B. Green (ed.), Dictionary of Jesus and the Gospels, vol. 2, pp. 535-540, InterVarsity Press, Downers Grove, IL.

Roth, H.D., 1997, The blind, the lame, and the poor. Character types in Luke-Acts, Sheffield Academic Press, Sheffield. (JSNT 144).

Sam, R.L.A., 2008, The love commandment of Jesus Christ in the Gospel of Luke and Its implication in the Indian context, ISPCK, Delhi.

Scheffler, E., 2006, 'Compassionate action: Living according to Luke's gospel', in J.G. van der Watt (ed.), Identity, ethics, and ethos in the New Testament, pp. 77-106, De Gruyter, Berlin. (BZNW 141).

Schnelle, U., 2009, Theology of the New Testament, Baker Academic, Grand Rapids, MI.

Seaford, R., 1998, 'Introduction', in C. Gill, N. Postlethwaite \& R. Seaford (eds.), Reciprocity in ancient Greece, pp. 1-12, OUP, Oxford.

Tannehill, R.C., 1996, Luke, Abingdon NT Commentaries, Abingdon Press, Nashville, TN.

Tannehill, R.C., 2014, 'Luke-Acts', in R.L. Brawley (ed.), The Oxford encyclopedia of the Bible and ethics Vol. 1, pp. 533-541, Oxford University Press, Oxford.

Trebilco, P., 2019, 'Salvation and gift in 1 John: Unconditioned, but not unconditional', in D.S. du Toit, C. Gerber \& C. Zimmermann (eds.), SÕTËRIA: Salvation in early Christianity and antiquity, pp. 498-516, Brill, Leiden.

Van der Watt, J.G., 2019, A grammar of the ethics of John, vol 1, Mohr Siebeck, Tübingen. (WUNTI)

Van Unnik, W.C., 1966, 'Die Motivierung der Feindesliebe in Lukas vi 32-35', NovT 8 284-300. https://doi.org/10.2307/1559996

Zimmermann, R., 2007, 'Berührende Liebe (Der barmherzige Samariter) - Lk 10, 30-35', in Zimmermann, R. (ed.), Kompendium der Gleichnisse Jesu, pp. 538-555, Gütersloher Verlagshaus, Gütersloh. 